\author{
С.В. Гузченко, Д.М. Козлов, С.М. Телюков
}

Харківський національний університет Повітряних Сил ім. I. Кожедуба, Харків

\title{
ОБГРУНТУВАННЯ ОБСЯГУ ЗАВДАНЬ, ЩО ВИРІШУЮТЬСЯ МОБІЛЬНИМИ ТАКТИЧНИМИ ГРУПАМИ ПІД ЧАС ВЕДЕННЯ БОЙОВИХ ДІЙ
}

В статті проведено аналіз сучасних збройних конфліктів. На основі проведеного аналізу визначено обтрунтований обсяг завдань, щуо можуть виконуватись мобільними тактичними групами під час ведення бойових дій. Дано визначення, щзо розуміється під мобільною тактичною групою, вказано ї̈ орієнтовний склад та особливості створення. Визначені можливі способи дій мобільних тактичних груп, в залежності від виду бою. Запропоновано подальший порядок та особливості проведення досліджень, щзо полягає у проведенні очінювання ефективності бойового застосування мобільних тактичних груп на основі відповідних показників з урахуванням завдань та обтрунтованого складу изих груп.

Ключові слова: мобільна тактична група, бойове завдання, операція, спосіб дій.

\section{Вступ}

Постановка проблеми. Сучасний військовополітичний стан в Україні та світі вимагає проводити дослідження щодо розробки нових та удосконалення існуючих принципів застосування військ. Тактика застосування механізованих частин та підрозділів Сухопутних військ Збройних Сил України (СВ 3СУ) в сучасних умовах не повинна обмежуватись вимогами бойових статутів [1-2]. Це пов'язано 3 тим, що специфіка бойових завдань, які покладаються на механізовані підрозділи тактичного рівня, умови, в яких вони повинні виконуватись, взагалі характер сучасної війни - все це, безумовно, вимагає застосування нешаблонних дій. Наприклад, при організації оборонного бою на імовірних напрямках дій противника характеристики ділянок, районів, що обороняються, безумовно повинні відповідати бойовим можливостям підрозділів (батальйонів, рот або взводів). Але в реальних умовах розміри ділянок та районів місцевості значно більші ніж ті, що спроможні обороняти підрозділи [3-4]. Також, швидкі (раптові) зміни як у військово-політичній, так і в бойовій обстановці є причиною не своєчасної реакції на ці зміни.

Безумовно, бойовими статутами передбачені підрозділи, які тимчасово створюються зі складу штатних підрозділів механізованої (танкової) бригади, і які посилюються відповідними силами і засобами [1-2; 5-6]. Цими підрозділами є тактичні групи (ротні або батальйонні), склад сил і засобів яких визначається змістом і обсягом завдань, що виконуються. Тактична група застосовується для самостійного виконання найбільш важливих тактичних завдань: утримання важливих районів, рубежів і позицій, відбиття наступу основного угруповання противника; прориву оборони противника, штурму і захо- плення важливих об'єктів; форсування водних перешкод, захоплення плацдармів, переслідування противника, що відходить; проведення рейдових, обхідних, ізоляційних, блокувальних, розвідувально-ударних дій, охорони важливих об'єктів і комунікацій [7-8]. Але, по-перше: створення, злагодження тактичних груп, їх передислокація, організація бою і т. ін. - все це потребує значної кількості часу; по-друге: при призначені роти або батальйону в якості основи тактичної групи приводить до зменшення бойових можливостей тих військових формувань, з яких вони призначені.

Таким чином, виникає протиріччя, з одного боку існує необхідність своєчасної реакції підрозділів на дії противника та зміну обстановки, з іншого боку - створення тактичних груп потребує багато часу, порівняно з часом реакції на дії противника, та приводить до зменшення бойових можливостей військових формувань, з яких призначені тактичні групи. Одним із шляхів вирішення вказаного протиріччя $€$ передбачення та використання мобільних тактичних груп, які, з одного боку, можуть забезпечити виграш в часі при зміні обстановки, а з іншого боку, створення мобільних груп не зменшує бойових можливостей тих військових формувань, $з$ яких вони призначені.

Мобільною тактичною групою (Моб.ТГр.) може бути штатний або тимчасово створений невеликій підрозділ (до взводу) на легкій броньованій або іншій техніці, що здатний в короткий термін виконати бойові завдання щодо стримуючих дій противника. Моб.ТГр. може бути вогневою, ударною, протитанковою і т. ін. Моб.ТГр. повинна бути готова до автономних дій на протязі терміну, визначеного старшим начальником, що приймає рішення на іiі застосування. Основу Моб.ТГр. складає механізований підрозділ СВ зі своїм штатним озброєнням 
при підтримці інших вогневих засобів. У цих умовах Моб.ТГр. виступають як самостійні тактичні одиниці, здатні оперативно вирішувати визначений спектр завдань.

Зацікавленість щодо використання Моб.ТГр. була обумовлена, перш за все, тим, що до основних переваг Моб.ТГр. відносяться:

- живучість;

- швидка маневреність;

- прихованість;

- транспортабельність різними видами транспорту;

- автономність дій;

- можливість використання різних видів озброєння та військової техніки, відповідно бойових завдань.

Також необхідність створення Моб.ТГр. обумовлена тенденціями розвитку збройної боротьби, а caмe:

- зміною змісту воєнних дій, які почали проводитися у формі мережецентричних операцій із широким застосуванням малих тактичних груп, здатних автономно виконувати бойові завдання у відриві від головних сил [9-10];

- зростанням можливостей армій провідних країн світу щодо одночасного дальнього вогневого пораження значної кількості бронеоб'єктів, що обумовлює неповне використання бойових можливостей у сучасних операціях (бойових діях) значних загальновійськових формувань (типу дивізій) через ïх громіздкість, а отже, і неможливість прихованого розгортання для застосування, та потребує формування та застосовування невеликих за чисельністю, різнопланових за бойовими можливостями, автономних і маневрених вогневих груп для виконання конкретних бойових завдань;

- активізацією та зростанням ролі диверсійнорозвідувальних груп противника та незаконних збройних формувань під час ведення операцій (бойових дій) і недостатньою кількістю відповідно підготовлених військових частин (підрозділів) для протидії зазначеним силам (формуванням) [11].

Останнім часом у спеціальних операціях загальновійськовими з'єднаннями і частинами спільно 3 формуваннями інших силових структур в основному проводяться розвідувально-пошукові, ударноштурмові, рейдово-блокувальні дії у протиборстві $з$ “нетиповим” противником [11]. Таким чином, для проведення подальших досліджень, наприклад, щодо визначення оптимального складу Моб.ТГр., організації управління та тактики дій цих груп - необхідно обгрунтовано визначити обсяг завдань, що повинні вирішуватись Моб.ТГр. під час ведення бойових дій.

Аналіз останніх досліджень і публікацій. Необхідність застосування невеликих мобільних так- тичних підрозділів почала суттєво зростати в ході ведення локальних війн та збройних конфліктів як у світі, так і на сході України [3-4; 11-14].

На теперішній час у воєнно-науковій літературі наводяться приклади тактичних дій, способів, завдань, що виконуються невеликими мобільними тактичними підрозділами різного складу [3; 11-12]. У [13-14] розглядається досвід створення та застосування угруповання військ (сил) в операціях другої половини XX - початку XXI століть. У роботах [8; 12-13] розглянуті зміни в тактиці дій підрозділів останніх десятиліть. У статях [7-10] визначається перспективний склад бойових підрозділів провідних країн світу. Але системних досліджень щодо визначення: обсягу завдань, які повинні вирішуватись Моб.ТГр.; оптимального складу Моб.ТГр.; ефективних способів застосування - не проводилось.

Метою статті $\epsilon$ визначення обгрунтованого обсягу завдань, що можуть вирішуватися мобільними тактичними групами під час ведення бойових дій на основі аналізу збройних конфліктів другої половини XX - початку XXI століть.

\section{Виклад основного матеріалу}

Виходячи $з$ досвіду ведення бойових дій малою чисельністю (так би мовити “нетрадиційних" бойових дій) 3 високою мобільністю, військовополітичним керівництвом провідних країн світу запропоновані нові концепції наземних бойових дій майбутнього, а саме [9]:

- “Комплексні бойові дії”,

- "Перспективна концепція наземних операцій”,

- “Розподіл операцій”.

Зазначеними документами передбачається застосування невеликих за чисельністю бойових груп (підрозділів), що спираються на загальну систему авіаційної та вогневої підтримки з малим часом реакції. Ці групи повинні бути інтегровані в єдину систему управління, зв'язку, спостереження та розвідки, що забезпечить їх гнучке та оперативне орієнтування при виконанні завдань, що раптово виникають. Виходячи з чисельності та характеру дій противника, Моб.ТГр. можуть об'єднуватися в більш великі формування або навпаки розосереджуватися по всій території [7;10]. Головними принципами нової концепції наземних бойових дій майбутнього $\epsilon[9]$ :

- децентралізована та різноманітна тактика дій автономних або напівавтономних підрозділів;

- спільний вплив усіх підрозділів на єдину ціль;

- різноманітні, але скоординовані за місцем i часом дії підрозділів, проведення атаки об’єкта противника з різних напрямків;

- відсутність поняття “тил” і дії за принципом 
“всюди фронт”;

- досконала система розвідки, управління, матеріально-технічного забезпечення;

- завдання щодо поразки противника як на значній відстані, так і в умовах безпосереднього зіткнення з ним;
- зосередження головних зусиль на підриві єдності сил противника.

Для обгрунтування ефективних способів і завдань, що вирішуються Моб.ТГр при веденні бойових дій, необхідно розглянути основні види завдань, які можуть виконувати тактичні групи (рис. 1).

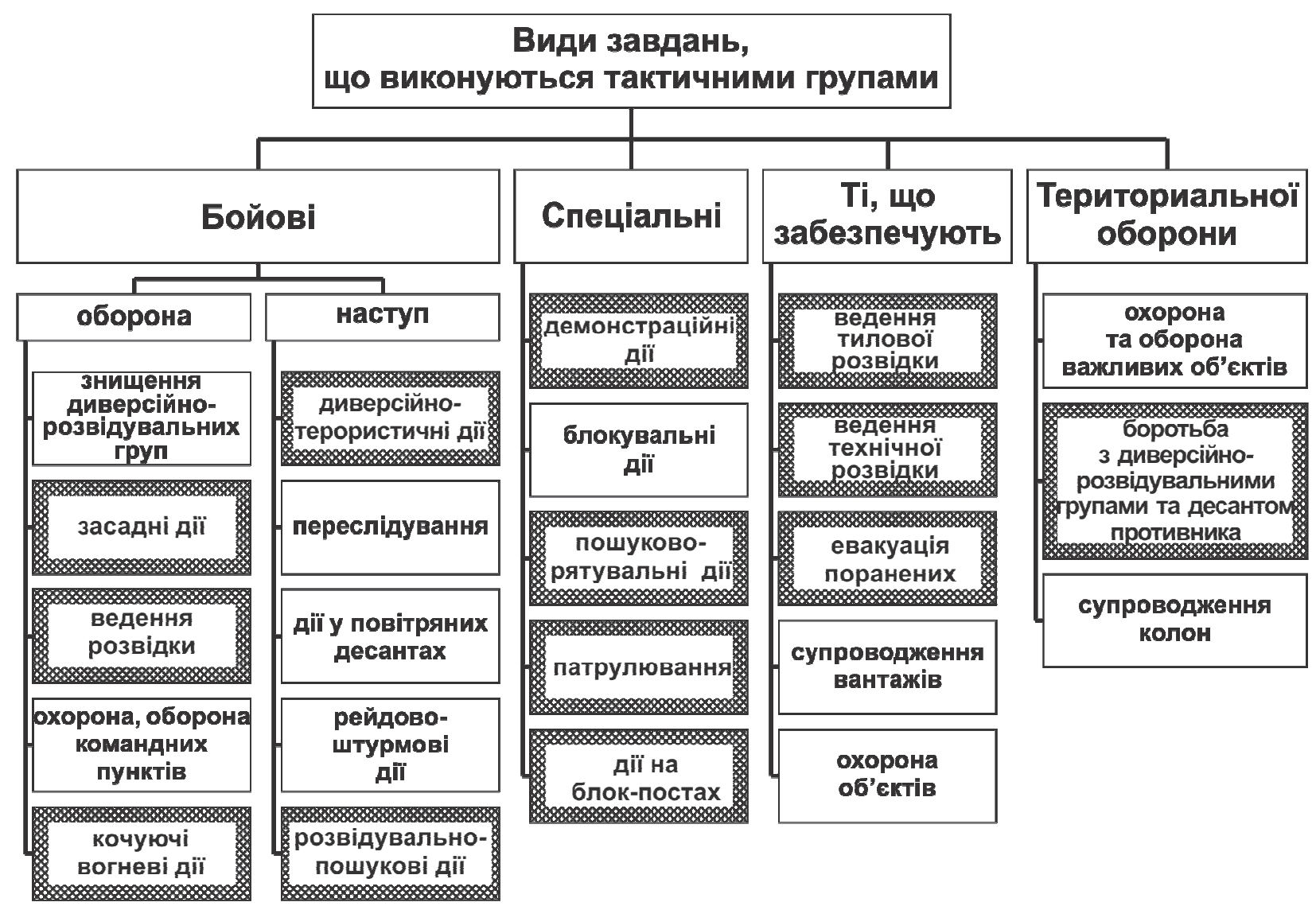

Рис. 1. Види завдань які можуть виконуватись тактичними групами

На рис. 1 позначено дії, які є найбільш характерними для Моб.ТГр. У цьому контексті необхідно розглядати Моб.ТГр. як один з елементів бойового порядку в сучасних тактичних діях. Але, для визначення обгрунтованого обсягу завдань, що повинні вирішуватись Моб.ТГр. під час ведення бойових дій, необхідно провести аналіз збройних конфліктів другої половини XX - початку XXI століть та на сході України.

Прикладами найбільш повної реалізації ефективних способів і завдань, що вирішуються мобільними вогневими групами під час ведення бойових дій на тактичному рівні, є дії частин і підрозділів на сході України, коаліційних сил в Іраку та війні в Афганістані [11;14]. Безпосереднім прикладом застосування Моб.ТГр. можна розглянути наступально (штурмові дії) підрозділів сил антитерористичної операції (АТО) при проведені операції “Миколаївка”. Штурмові загони складалися з розвідувальних, штурмових, мобільних, вогневих, інженерних, спеціальних груп. Дії груп підтримувала артилерія, аві- ація Повітряних Сил (ПС) та Сухопутних військ (CВ) Збройних Сил України (ЗСУ). Дані групи здійснювали: розвідку, пошук, наведення авіації та вогонь артилерії на позиції противника, штурм та знищення вогневих засобів і живої сили противника на позиціях та опорних пунктах, утримання блок постів. Таким чином, на кінець доби в результаті ведення спеціальних дій Моб.ТГр. сил АТО оволоділи шістьма опорними пунктами бойовиків, блокували 3 чотирьох сторін м. Миколаївка та зайняли вигідні положення на рубежі блокування для забезпечення зачистки підрозділами Національної Гвардії України. Крім того, взято під контроль ділянку дороги Харків - Ростов південніше м. Слов'янськ. На наступну добу Моб.ТГр. сил АТО завершили зачистку м. Миколаївка, звільнили ії від бойовиків, виконали завдання в цілому операції "Миколаївка" та закріпилися на визначених рубежах, це дало змогу нанести значних втрат бойовикам, що призвело до повної їх деморалізації, що, в свою чергу, у подальшому призвело до здачі ними м. Слов'янськ, 
м. Краматорськ та м. Сіверськ, відновлення правопорядку та інфраструктури звільнених населених пунктів.

Виконанню завдання сприяло наступне:

- проведення розвідки та дорозвідки об'єктів противника;

- нанесення ураження ударами авіації ПС та артилерії по іншим позиціям противника;

- одночасне висування всіх тактичних груп в райони виконання завдань;

- створення вогневих коридорів та радіоелектронного придушення для забезпечення безперешкодного висування тактичних груп.

Ще одним прикладом завдань, що вирішуються Моб.ТГр. групами на сході України при веденні оборонних дій, $є$ дії зенітних мобільних вогневих груп, до складу яких входили 1-2 засоби ППО малої дальності, 1-2 засоби ППО ближньої дії та підрозділ безпосереднього прикриття (у складі механізованого відділення). У окремих випадках до складу групи були включені засоби ППО середньої дальності. Мобільна вогнева група була готова до автономних дій на протязі терміну, визначеного старшим начальником, що приймає рішення на іiі застосування. Завданнями зенітної мобільної вогневої групи були наступні:

- унеможливлення ведення повітряної розвідки противником;

- примушення повітряного противника до ведення повітряної розвідки (нанесенню ударів) 3 більш великих висот та з невигідних напрямків;

- знищення засобів повітряного нападу (ЗПН) противника, що можуть діяти у проміжках зон пораження сил та засобів ППО.

Прикладом застосування Моб.ТГр. в ході наступу є дії підрозділів, які рухалися в авангарді наступаючих бригад в Іраку [11]. На територію противника були скеровані чотири мобільні групи на машинах “Land Rover” та мотоциклах. Їм були поставлені наступні завдання: виявлення пускових установок Р-17, наведення авіації на виявлені ракетні установки, розвідка результатів нанесення ударів, самостійне знищення пускових установок (ПУ). До складу мобільних груп входило 12 машин та 2-3 мотоцикли. На кожній машині знаходилось три військовослужбовця: командир, водій та стрілок-оператор важкої зброї. Як вогнева установка на машинах розміщувалися ПТРК “Мілан”; 12,7-мм кулемет М2НВ або автоматичний гранатомет “Мк-19”. Викривши пускові установки ракет Р-17, командир загону або групи визначав їх координати за допомогою приладу супутникової навігаційної системи GPS передавав координати в центр управління. Інколи при завданні авіаційних ударів бійці мобільних груп допомагали у наведенні за допомогою лазерних засобів цілевказання. Дії мобільних груп 3 пошуку та знищення ракетних комплексів Р-17 були ефективними [4].

Також, заслуговують увагу дії невеликих груп 2 обркп США по зачистці міста Ель-Кут при проведені військової операції Багатонаціональних сил в Іраку в 2004 році. Після захоплення кварталів міста наземними силами, спеціальні мобільні групи (до 7 автомобілів "Нummer" в кожній) проводили планове “зачищення” будинків. В цей період всі головні вулиці кварталу блокувались танками або бойовими машинами піхоти (БМП). Для ліквідації випадків збройного опору залучались також вертольоти та літак вогневої підтримки [11].

Виходячи 3 прикладу спеціальної військової операції по “зачищенню” ЗС США “Бунтівний ятаган” необхідно відзначити фактори, які привели до швидкого успіху операції:

- висока ефективність всіх видів розвідки, зв’язку та цілевказання, а також засобів ведення бою в нічний час;

- широке застосування потужної обчислювальної техніки для збору, обробки та розподілу розвідувальної інформації, а також планування бойових дій;

- високий професіоналізм особового складу 3 питання ведення бойових дій в місті в нічних умовах;

- наявність ефективних засобів повітряної підтримки ЗС США та налагодженої взаємодії між ними та наземними силами;

- оптимізація складу бойових груп та їх озброєння для ведення бойових дій в місті;

- якісне всебічне забезпечення операції.

Показовим $є$ застосування мобільних тактичних груп при проведені розвідувально-пошукових дій під час війни в Афганістані. Мобільні групи на автомобілях “Toyota" та "Semurgi”, також в кузові вантажних автомобілів типу “ЗИЛ” та “КрАЗ”, що були залишені в минулому на базах радянських військ, виїжджали на дорогу у визначеному місті і робили вигляд каравану “моджахедів”. Використовуючи такий спосіб дезінформації, мобільні групи висувалися в визначений район для здійснення пошуку та знищення противника. Таку тактику дій застосовували і вогневі групи 1 мб 92 омбр при ведені бойових дій на сході України використовуючи цивільні транспортні засоби для скритого переміщення в район виконання завдання, приховано займали позиції вночі, та зранку атакою у фланг знищували противника [13].

Добре себе показала тактика дій дрібних вогневих груп чеченських збройних сил, щоб протистояти військам Російської Федерації (РФ). Разом з традиційними формами дія чеченських підрозділів була спрямована на широкомасштабні наступальні і оборонні дії по захопленню і утриманню важливих стратегічних об'єктів, що характеризувалось широким спектром проявів, від терористичних акцій до 
відкритих збройних виступів дрібними (15-20 чол.) групами. Разом з тим, як і раніше, основоположними принципами тактики дій дрібних груп є раптовість, рішучість, зухвалість і мала тривалість ведення бойових дій. Найважливішим чинником, що визначає специфіку дій дрібних груп, є проведення систематичних, так би мовити, “турбуючих” дій, які примушують війська вдаватися до оборонної тактики, як це було впродовж практично двох місяців в прикордонних районах 3 Чечнею та Дагестаном. Більше того, вони створюють враження про здатність завдавати ударів в будь-якому місці, часом зовсім несподіваному. "Турбуючі" і “виснажуючі" дії складають основу тактики дій збройних формувань, що прагнули, як правило, відхилитися від прямого зіткнення 3 потужними силами військ РФ. В основі їх дій у цьому випадку лежить відкриття вогню на випередження, який повинен вестись переважно 3 коротких дистанцій.

Потребують уваги дії Моб.ТГр. при проведені засідок. В якості прикладу можна розглянути дії загонів Афганських повстанців проти радянських військ в районі міста Саідабад провінції Вардак [13] Створивши три основні групи (нападу, підтримки та групу важкого озброєння - кількістю до 30 чоловік в кожній), атакували колону радянських військ. Протягом двох годин, користуючись пасивністю дій радянських військ, які не намагаючись протидіяти підрозділам Афганських повстанців, вели лише вогонь 3 дороги, група нападу знищила 17 одиниць бронетехніки, 45 вантажних автомобілів та паливозаправників (автоцистерн). Після знищення бронетехніки повстанці атакували залишки колони на дорозі та завершили ії розгром, при цьому захопивши 4 од. нових на той час автоматів АК-74. Таким чином, внаслідок проведених дій повстанцями було повністю розгромлено велику радянсько-афганську колону, при цьому втрати вбитими склали лише 10 чол. Виходячи з аналізу збройних конфліктів другої половини XX - початку XXI століть та на сході України, можна визначити способи дій Моб.ТГр. в ході наступу та під час оборони.

В ході ведення наступу:

- забезпечення завершення розгрому противника діями мобільних тактичних груп СВ і морської піхоти за підтримкою авіації з широким застосуванням дій сил спеціальних операцій, повітряних десантів після розгрому противника оперативно-тактичними угрупованнями своїх військ;

- зосередження зусиль на вибраних ділянках за рахунок мобільності та маневру, з метою порушення оперативної та тактичної стійкості оборони противника довготривалим і безперервним масованим електронно-вогневим впливом у сполученні з наступним охопленням військами (силами) по землі та повітрю, створенням активно діючого фронту в тилу противника;

- ведення активних розвідувально-пошукових дій, проведення відволікаючих ударів, спільних операцій сил спеціального призначення разом із механізованими і танковими частинами сухопутних військ.

Під час ведення оборони основну увагу необхідно зосередити на аеромобільній, розосередженій, стримуючій, блокуючій, демонстративній (хибній) обороні, що побудована за принципом осередкованих дій $[3 ; 7 ; 10-12]$. Застосування нових способів i форм ведення оборони здійснюється у зв'язку з тим, що підрозділи повинні готуватися до ведення бойових дій як у великомасштабній війні, так і в регіональних, локальних війнах і різноманітних збройних конфліктах, кожен з яких є унікальним. Протиборство в них може вестись 3 різним за технічним оснащенням і навченістю противником, у том числі й нерегулярних формувань, які використовують тактику партизанських, диверсійно-терористичних дій, що мало місце під час війни на сході України, коаліційних сил в Іраку та в Афганістані.

Виходячи з аналізу, при веденні оборони можливо визначити такі способи та завдання, що доцільно вирішувати силами Моб.ТГр.:

- при діях у складі угрупування, що обороняється, Моб.ТГр. слід використовувати у якості протидесантного резерву для знищення десантів, диверсійно-розвідувальних груп противника та незаконних збройних формувань, як самостійно, так і у взаємодії з загальновійськовим резервом та підрозділами ППО;

- ведення засадних дій $з$ рейдовими загонами противника, які просочуються в тил через проміжки і розриви у бойових порядках військ, що потребує вживати заходів щодо організації в глибині оборони надійної охорони й оборони пунктів управління, вогневих позицій ракетних військ і артилерії, сил і засобів ППО, тилових органів і комунікацій, надійного прикриття та забезпечення відкритих флангів і стиків самостійних дій підрозділів ланки рота - батальйон;

- осередкована оборона в бойових порядках у складних фізико-географічних умовах району бойових дій, що змушує застосовувати сухопутні угруповання військ (сил) за певними напрямками уздовж доріг змішаними невеликими тактичними групами, як правило, у перед бойових порядках, 3 виткою зміною позицій;

- асиметричне застосування "ройової тактики" (“тактики зграї”, “тактики мурашника”, “тактики бойових груп”) під час ведення оборонних, партизанських дій, завдання противнику значних втрат, 3 метою примушення його відмовитись від подальших дій;

- оборона опорних баз, коли необхідно посили- 
ти невеликі за складом підрозділи охорони за рахунок швидкого пересування повітрям (головним чином вертольотами) аеромобільних підрозділів.

Можливо вважати, що в подальшому така оборона, у зв'язку з інтенсивним розвитком авіаційних засобів, знайде достатньо широке використання, особливо з початком воєнних дій, коли виникає багато нових завдань, які потребують швидкого реагування на критичний розвиток подій, з метою прикриття проміжків і розривів в бойовому шикуванні військ, що з'являються, переміщенням підрозділів повітрям;

- оборона нерівномірно розподіленими силами та засобами по фронту та в глибині оборони, що дає можливість Моб.ТГр. під час ведення бойових дій мати можливість здійснити широкий маневр.

Широке застосування в такій обороні засадних дій, створення рухомих загороджень керованих мінних полів;

- оборона при раптовому нападі противника, його перевазі в силах і засобах на важливих напрямках. Моб.ТГр. ведуть стримуючі дії, використовуються епізодично, коли необхідно виграти час, щоб скувати дії наступаючого противника. Широко використовуються загородження усіх видів, встановлення засідок, пасток, створення вогневих мішків, загороджувальних вибухово-вогневих бар'єрів;

- блокуючі дії в ході боротьби з повітряними десантами, рейдовими, диверсійно-розвідувальними, обхідними підрозділами противника, що діють в тилу оборони військ;

- перехоплення шляхів маневру, стримування дій противника загороджувальним вогнем, створення заслонів, встановлення міно-вибухових загороджень дистанційними засобами.

Можна впевнено сказати, що із застосуванням Моб.ТГр. зміняться способи та завдання, що вирішуються підрозділами під час ведення сучасної оборони.

Оборона стрімко еволюціонує у бік підвищення самостійності, асиметричності застосування сил, активності, мобільності, маневреності, захищеності від високоточної зброї, широкого використання всіх видів загороджень.

\section{Висновки}

1. На основі аналізу військових конфліктів останніх десятиліть можна відзначити, що зміни в способах ведення бойових дій відбуваються в напрямку ведення "нетрадиційних" бойових дій, застосування формувань малої чисельності, гнучкості та мобільності підрозділів, включення до складу формувань підрозділів різних родів військ ЗС.

2. При веденні сучасних бойових дій, Моб.ТГр. доцільно використовувати для виконання наступних завдань:

- прикриття ділянок державного кордону;

- відбиття наступу підрозділів сухопутних військ противника й утримання районів, рубежів і важливих об'єктів;

- участі у стабілізаційних діях (ліквідація, локалізація, нейтралізація збройного конфлікту);

- боротьби 3 нерегулярними збройними формуваннями та диверсійно-розвідувальними силами противника на власній території;

- сумісного виконання (у складі тактичних груп) специфічних завдань сучасних операцій військовими частинами, підрозділами, органами інших військових формувань і правоохоронних органів держави.

3. Найбільш доцільними способами застосування Моб.ТГр. є:

- асиметричне застосування (“ройова тактика”, “тактика зграї”, “тактика мурашника”, “тактика бойових груп”);

- створення активно діючого фронту в тилу противника (диверсійно-розвідувальні та пошукові дії);

- проведення відволікаючих ударів;

- посилення невеликих за складом підрозділів охорони за рахунок швидкого пересування;

- ведення стримуючих дій;

- блокуючі дії при боротьбі з повітряними десантами, рейдовими, диверсійно-розвідувальними, обхідними підрозділами противника;

- перехоплення шляхів маневру;

- створення заслонів.

4. Для оцінювання ефективності бойового застосування Моб.ТГр. необхідно визначити сукупність відповідних показників з урахуванням завдань та обгрунтованого складу Моб.ТГр.

\section{Список літератури}

1. Бойовий статут механізованих і танкових військ Сухопутних військ Збройних Сил України. Частина 2 (батальйон (рота)). - К.: ЗС України, 2016. - 351 с.

2. Бойовий статут механізованих і танкових військ Сухопутних військ Збройних Сил України. Частина 3 (взвод, відділення, екіпаж). - К.: ЗС України, 2016. - 229 с.

3. Зайцев Д.В. Деякі погляди та правові аспекти розвитку тактики за досвідом локальних війн і збройних конфліктів сучасності / Д.В. Зайцев, В.А. Шевчук // Форум права. - 2016. - № 5. - С. 41-47.

4. Стрижевський В.В. Розвиток загальної тактики в локальних війнах і збройних конфліктах другої половини ХХ та на початку XXI століть: монографія / В.В. Стрижевський. - К.: НАОУ, 2006. - 272 с.

5. Field Manual 3-90-1. Offense and Defense. Vol. 1. - Washington: Headquarters Department of the Army, 2013. - 288 p. 
6. Field Manual 3-21.20 (7-20). The infantry battalion. - Washington: Headquarters Department of the Army, 2006. $600 \mathrm{p}$.

7. Сатаров В. Развитие форм и способов боевых действий Сухопутных войск США / В. Сатаров, Н. Балуков // Зарубежное военное обозрение. - 2012. - № 1. - С. 40-44.

8. Федоренко В.В. Розвиток тактики за досвідом локальних війн кінця XX - початку XXI століть / В.В. Федоренко // Наука і оборона. - 2007. - № 3. - С. 31-35.

9. Корчагин С. Зарубежные концепции ведения нетрадиционных боевых действий в локальных конфликтах / С. Корчагин // Зарубежное военное обозрение. - 2007. - № 8. - С. 3-7.

10. Рябинин А. Нетрадиционные военные операции ВС зарубежных государств / А. Рябинин // Зарубежное военное обозрение - 2005. - № 6. - С. 2-9.

11. Збірник оперативних і тактичних прикладів дій військ (сил) у збройних конфліктах сучасності. - К: ГШ ЗС України, 2013. - 135 с.

12. Рукшин А.С. Военное искусство в локальных войнах и вооруженных конфликтах / А.С. Рукшин. - М.: Воениздат, 2009. - 764 c.

13. Телелим В.М. Досвід створення та застосування угруповань військ (сил) у локальних війнах і збройних конфліктах другої половини XX та на початку XXI століття: монографія / В.М. Телелим, О.М. Загорка, В.В. Стрижевський. К.: НУОУ, 2012. -336 c.

14. Локальні війни та збройні конфлікти другої половини XX століття (Історико-філософський аспект): монографія / О.І. Гуржій, С.П. Мосов, В.Д. Макаров та ін. - К.: Знання, 2006. - 356 с.

\section{References}

1. The Armed Force of Ukraine (2016), "Boiovyi statut mekhanizovanykh i tankovykh viisk Sukhoputnykh viisk Zbroinykh Syl Ukrainy. Chastyna 2, batalion (rota)" [Military Status of the Mechanized and Tank Army of the Land Forces of the Armed Forces of Ukraine. Part 2, battalion (company)], Kyiv, $351 \mathrm{p}$.

2. The Armed Force of Ukraine (2016), "Boiovyi statut mekhanizovanykh i tankovykh viisk Sukhoputnykh viisk Zbroinykh Syl Ukrainy. Chastyna 3, vzvod, viddilennya, ekipazh)" [Military Status of the Mechanized and Tank Army of the Land Forces of the Armed Forces of Ukraine. Part 3, platoon, compartment, crew], Kyiv, 229 p.

3. Zajcev, D. and Shevchuk, V. (2016), "Deyaki poglyady ta pravovi aspekty rozvytku taktyky za dosvidom lokalnykh vijn i zbrojnykhkonfliktiv suchasnosti" [Some views and legal aspects of the development of tactics in the experience of local wars and armed conflicts of today], Forum of Law, No. 5, pp. 41-47.

4. Stryzhevskyj, V.V. (2006), "Rozvytok zagalnoyi taktyky v lokalnykh vijnah i zbrojnykh konfliktakhdrugoyi polovyny 20 ta na pochatku 21 stolit" [Development of common tactics in local wars and armed conflicts in the second half of the 20th and early 21st centuries], National Academy of Defense of Ukraine, Kyiv, 272 p.

5. Headquarters Department of the Army (2013), Field Manual 3-90-1.Offense and Defense Vol. 1, Washington, 288 p.

6. Headquarters Department of the Army (2006), Field Manual 3-21.20 (7-20). The infantry battalion, Washington, $600 \mathrm{p}$.

7. Satarov, V. and Balukov, N. (2012), "Razvytye form y sposobov boevikh dejstvyj Suhoputnikh vojsk SShA" [The development of forms and methods of military operations of the Army of US], Foreign Military Review, No. 1, Moscow, pp. 40-44.

8. Fedorenko, V. (2007), "Rozvytok taktyky za dosvidom lokalnykh vijn kincya XX - pochatku XXI stolit" [The development of tactics based on the experience of local wars of the late XX - early XXI centuries], Science and Defense, No. 3, pp. 31-35.

9. Korchagyn, S. (2007), "Zarubezhnie koncepcyy vedenyya netradycyonnih boevih dejstvyj v lokalnih konflyktah" [Foreign concepts of conducting unconventional military operations in local conflicts], Foreign Military Review, No. 8, Moscow, pp. 3-7.

10. Ryabynyn, A. (2005), "Netradycyonnie voennie operacyy vooruzhennih syl zarubezhnih gosudarstv" [Unconventional military operations of the armed forces of foreign states], Foreign Military Review, No. 6, Moscow, pp. 2-9.

11. General Staff of the Forces of Ukraine (2013), "Zbirnyk operatyvnykh i taktychnykh prykladiv dij vijsk (syl) u zbrojnykh konfliktakh suchasnosti" [Digest of operational and tactical examples of the forces in the armed conflicts of our time], Kyiv, $135 \mathrm{p}$.

12. Rukshyn, A.S. (2009), "Voennoe yskusstvo v lokalnih vojnah y vooruzhennih konflyktah" [Military art in local wars and armed conflicts], Military publishing, Moscow, $764 \mathrm{p}$.

13. Telelym, V.M., Zagorka, O.M. and Stryzhevskyj, V.V. (2012), "Dosvid stvorennya ta zastosuvannya ugrupovan vijsk (syl) u lokalnyh vijnah i zbrojnykh konfliktah drugoyi polovyny 20 ta na pochatku 21 stolittya" [The experience of creating and using groups of troops (forces) in local wars and armed conflicts in the second half of the 20th and early 21st centuries], National Academy of Defense of Ukraine, Kyiv, $336 \mathrm{p}$.

14. Gurzhij, O.I., Mosov, S.P. and Makarov, V.D. (2006), “Lokalni vijny ta zbrojni konflikty drugoyi polovyny XX stolittya (Istoryko-filosofsky 'j aspekt)" [Local wars and armed conflicts of the second half of the XX century (Historical and philosophical aspect)], Znannya Publishing House, Kyiv, 356 p. 
Відомості про авторів:

Гузченко Сергій Вікторович

кандидат військових наук

начальник кафедри

Харківського національного університету

Повітряних Сил ім. І. Кожедуба,

Харків, Україна

https://orcid.org/0000-0002-3562-6172

\section{Козлов Дмитро Михайлович}

старший викладач

Харківського національного університету

Повітряних Сил ім. I. Кожедуба,

Харків, Україна

https://orcid.org/0000-0002-5647-0218

Телюков Сергій Миколайович

кандидат технічних наук

старший викладач

Харківського національного університету

Повітряних Сил ім. І. Кожедуба,

Харків, Україна

https://orcid.org/0000-0002-0067-8028
Information about the authors:

\author{
Segiy Guzchenko \\ Candidate of Military Sciences \\ Head of Department \\ of Ivan Kozhedub Kharkiv National \\ Air Force University, \\ Kharkiv, Ukraine \\ https://orcid.org/0000-0002-3562-6172
}

\author{
Dmitro Kozlov \\ Senior Instructor \\ of Ivan Kozhedub Kharkiv National \\ Air Force University, \\ Kharkiv, Ukraine \\ https://orcid.org/0000-0002-5647-0218
}

Segiy Telyukov

Candidate of Technical Sciences

Senior Instructor

of Ivan Kozhedub Kharkiv National

Air Force University,

Kharkiv, Ukraine

https://orcid.org/0000-0002-0067-8028

\title{
ОБОСНОВАНИЕ ОБЪЕМА ЗАДАНИЙ, КОТОРЫЕ РЕШАЮТСЯ МОБИЛЬНЫМИ ТАКТИЧЕСКИМИ ГРУППАМИ ВО ВРЕМЯ ВЕДЕНИЯ БОЕВЫХ ДЕЙСТВИЙ
}

\author{
С.В. Гузченко, Д.М. Козлов, С.Н. Телюков
}

В статье проведен анализ современных вооруженных конфликтов. На основе проведенного анализа определен обоснованный объем заданий, которые могут выполняться мобильными тактическими группами во время ведения боевых действий. Дано определение, что понимается под мобильной тактической группой, указан ее ориентировочный состав и особенности создания. Определены возможные способы действий мобильных тактических групп, в зависимости от вида боя. Предложен дальнейший порядок и особенности проведения исследований, который состоит в проведении оценивания эффективности боевого применения мобильных тактических групп на основе соответствующих показателей с учетом заданий и обоснованного состава этих групп.

Ключевые слова: мобильная тактическая группа, боевое задание, операчия, способ действий.

\section{JUSTIFICATION OF THE VOLUME OF TASKS THAT ARE SOLVED BY MOBILE TACTICAL GROUPS DURING THE CONDUCT OF BATTLE ACTIONS}

\section{S. Guzchenko, D. Kozlov, S. Telyukov}

The article analyzes modern armed conflicts. It is determined that the tactics of using mechanized units and units of the ground forces in modern conditions should not be limited to the requirements of combat manuals. This is due to the fact that the specifics of combat missions, which are set for mechanized units of a tactical level, the conditions under which they must be fulfilled, the general nature of modern warfare, all this, of course, requires the use of unconventional actions. A contradiction is defined, which consists in the fact that, on the one hand, there is a need for timely reaction of units to enemy actions, a change in the situation, on the other hand, the creation of tactical groups requires a lot of time compared to the reaction time to enemy actions, and leads to a decrease in the combat capabilities of the military formations. One way to resolve this contradiction is to use mobile tactical groups, which on the one hand can provide time gain when the situation changes, and on the other hand, the creation of mobile groups does not reduce the combat capabilities of the military formations from which they are assigned. Based on the analysis, a reasonable amount of tasks that can be performed by mobile tactical groups during the conduct of hostilities is determined. A definition is given of what is meant by a mobile tactical group, namely this full-time or temporary created small unit (before the platoon) using lightly armored or other equipment that is capable of completing combat missions for deterring enemy operations in a short time. The indicative composition and features of creating a mobile group are indicated. Possible methods of action of mobile tactical groups are determined, depending on the type of battle. A further order and features of research are proposed, which consists in assessing the effectiveness of the combat use of mobile tactical groups based on relevant indicators, taking into account tasks and the reasonable composition of these groups. It is safe to say that using mobile tactical groups will change the methods and tasks that are decided by units during modern defense. This is due to the fact that defense, as a type of battle, is rapidly evolving towards increasing independence, asymmetric use of forces, activity, mobility, maneuverability and security.

Keywords: mobile tactical group, combat mission, operation, mode of action. 